\title{
S.K. TRIMURTI: PEJUANG PEREMPUAN INDONESIA
}

\author{
Ipong Jazimah \\ Pendidikan Sejarah, Universitas Muhammadiyah Purwokerto
}

\begin{abstract}
Abstrak. S.K. Trimurti adalah seorang tokoh perempuan yang memiliki peran sangat besar dalam perjuangan Indonesia. Berguru langsung kepada Soekarno dan berpartisipasi aktif dalam Partindo adalah salah satu fase penting yang membentuk kepribadian dan jiwa perjuangannya. Dikenal berani, lantang, dan sangat nasionalis S.K. Trimurti saat itu cukup merepotkan pemerintah Belanda. Kesimpulan dari artikel ini menunjukkan bahwa perempuan juga mempunyai tempat yang sama pentingnya dengan laki-laki di masa perjuangan kemerdekaan dan setelahnya. Dibuktikan dengan posisi S.K. Trimurti sebagai ketua Partai Buruh Indonesia, ketua Barisan Buruh Wanita, Ketua Gerwis, Menteri Perburuhan, dan juga pemimpin surat kabar seperti Pesat dan Mawas Diri. Sebagai bagian dari historiografi, tulisan singkat ini tidak mengabaikan metode penelitian historis yang terdiri dari 4 langkah yaitu: (1) heuristik (pengumpulan sumber) yang berupa buku dan surat kabar; (2) kritik sumber dalam rangka mendapatkan sumber yang akurat; (3) interpretasi atau penafsiran terhadap data-data; (4) historiografi atau penyajian data.
\end{abstract}

Kata-kata kunci: Tokoh perempuan, S.K. Trimurti, wartawan nasionalis

\begin{abstract}
S.K. Trimurti is a figure having a significant role in pursuing Indonesian Independence. She inspired by Soekarno and actively participating in Partindo is one phase shaping her personality and her spirit of struggle. She is well-known as a brave and nationalistic woman. She is also known as a stone for the Dutch government. It could be clearly seen that woman has also a place in the period of Indonesian revolution. S.K. Trimurti roles as a chair of Indonesian Labour party, a chair of Women Labour, a chair of Gerwis, a Ministry of labour, and a chair of some newspapers of Pesat and Mawas Diri. As a part of historiography, this short article does not ignore the historical method. This method consisted of four steps of (1) heuristic of books and newspapers; (2) verification in searching accurate data; (3) interpretation on teh data; and (4) historiography.
\end{abstract}

Keywords: woman figure, S.K.Trimurti, nationalistic journalist

Sejarah perjuangan kaum perempuan dalam penulisan sejarah di Indonesia agak terpinggirkan. Bukan karena mereka tidak ada namun kalah oleh banyaknya tulisan tentang peranan kaum laki-laki. Artinya tulisan sejarah di Indonesia bisa dikatakan masih bersifat male domain, dimana laki-laki selalu menjadi tokoh utama dan perempuan sebagai pemeran pembantu. Tulisan ini bermaksud untuk mengangkat salah satu tokoh perempuan yang terlibat langsung dalam arus perjuangan kemerdekaan Indonesia yaitu S.K. Trimurti yang bernama asli Surastri.

Menurut sejarawan Kuntowijoyo, sejarah yang ditulis dengan kaum laki-laki sebagai tokoh utama dan perempuan sebagai pemeran pembantu adalah sejarah yang masih bercorak androcentric (Kuntowijoyo, 2013:115). Perempuan masih menempati kedudukan sebagai second sex atau dengan kata lain di belakang layar. Tulisan sejarah yang gynocentric masih harus terus dikembangkan dengan mengambil berbagai tema diantaranya perempuan dalam berbagai bidang seperti ekonomi, sosial dan budaya, biografi perempuan, atau tentang gerakan perempuan. Tulisan sejarah yang gynocentric setidaknya harus menempatkan perempuan sebagai tokoh utama.

Sebenarnya sejak masa kerajaan HinduBudha di Indonesia, banyak tulisan sejarah yang telah membuktikan bahwa perempuan juga kerap menduduki posisi sentral. Ann Kumar, sejarawan dari Australia dalam bukunya 
Prajurit Perempuan Jawa: kesaksian Ikhwal Istana dan Politik Jawa Akhir Abad Ke-18 membuktikan bahwa perempuan duduk sebagai prajurit penting pada masa kekuasaan kraton Mangkunegara di Surakarta. Para perempuan itu bersikap layaknya prajurit laki-laki yang dikenal gagah perkasa. Kenyataan itulah yang harus terus digali dan ditulis sehingga sejarah tak hanya melulu milik laki-laki.

Tulisan ini bermaksud untuk memberi porsi lebih pada perempuan di lingkup sejarah Indonesia masa sebelum, menjelang dan sesudah kemerdekaan. Sebenarnya ada beberapa nama perempuan lain yang juga mempunyai peran cukup penting dalam perjuangan kemerdekaan Indonesia, namun karena tulisan ini ingin memfokuskan pada S.K. Trimurti saja.

S.K. Trimurti dikenal sebagai seorang wartawati. Tulisannya tajam dan cenderung berani sehingga menimbulkan kecurigaan pemerintah Belanda. Namun demikian S.K. Trimurti tak pernah merasa gentar atau menyerah. Semangat perjuangannya tak pernah padam. Semangat itu diperoleh karena melihat sendiri bagaimana tindakan diskriminatif yang dilakukan oleh para penjajah terhadap rakyat. Bagi S.K. Trimurti, pers juga senjata ampuh untuk mengobarkan semangat kemerdekaan di tengah tekanan para penjajah walaupun usaha surat kabarnya harus berulangkali gulung tikar.

Posisi perempuan secara tradisional sangat dibatasi. Kewajiban mereka diranah domestik dan ikatan-ikatan budaya membuat perempuan tak bisa bebas terjun ke ranah publik. Sebenarnya S.K. Trimurti dilahirkan dengan latar belakang keluarga seperti ini, namun ia menentangnya dengan keras. Keterlibatan perempuan dalam organisasi politik formal seperti yang dilakoni oleh SK. Trimurti adalah bentuk perwujudan kesadaran politik perempuan (Ratih, 2009:29). Perempuan tak harus melulu di ranah domestik. Tak bisa dipungkiri memang bahwa kebangkitan perempuan tersebut juga karena kebangkitan nasionalis anti-kolonial yang kencang berhembus di kalangan para intelektual.
Soekarno sebagai sosok nasionalis yang amat dikenal masa pergerakan, bisa dikatakan maha guru bagi S.K. Trimurti. Pengaruh ajaran Soekarno menjadi tombak bagi S.K. Trimurti untuk berjuang tanpa takut dengan rintangan. Keberanian S.K. Trimurti untuk berjuang melawan Belanda berangkat dari kekagumannya atas ajaran Soekarno yang saat itu disampaikan lewat pidato-pidatonya (Chudori, 1993:206). Bahkan kemudian model perjuangannya pun mengikuti gaya Soekarno, yaitu terbuka, berani, dan non kooperatif.

Perempuan dan laki-laki tak bisa terpisahkan secara kodratnya. Behind every great man, there's great woman. Pepatah ini tepat untuk menggambarkan sepak terjang S.K. Trimurti dalam pergulatannya di dunia politik maupun pers. Di samping S.K. Trimurti ada nama besar Sayuti Melik pengetik naskah proklamasi, yang merupakan suaminya. Mereka dipertemukannya dalam panasnya arus politik masa penjajahan Belanda sampai kemudian menyeret keduanya untuk terlibat secara langsung dalam upacara paling bersejarah yaitu proklamasi 17 Agustus $1945 \mathrm{di}$ Jalan Pegangsaan Timur no. 56 Jakarta.

Menurut Kuntowijoyo, penulisan sejarah perempuan dapat mengambil tema diantaranya wanita dalam politik. Tema ini sejalan dengan arah pikiran tulisan ini yang akan mengupas bagaimana sepak terjang SK. Trimurti dalam politik di Indonesia sebelum kemerdekaan dan setelah kemerdekaan. Dengan tetap mengikutsertakan perjalanan hidup yang lainnya seperti keikutsertaanya dalam organisasi perempuan dan perjuangannya di bidang pers.

\section{S.K. TRIMURTI DAN DUNIA PERPOLI- TIKAN INDONESIA}

S.K. Trimurti lahir pada 11 Mei 1912 di Desa Sawahan Boyolali Karesidenan Surakarta. Ayahnya bernama R.Ng. Salim Banjaransari Mangunsuromo dan ibunya bernama R.A. Saparinten Mangunbisomo. Ayah dan ibunya terhitung masih abdi dalem Keraton 
Kasunanan Surakarta. Sekolah Dasar ditempuhnya di sekolah Ongko Loro atau Tweede Inlandsche School (TIS). Lulus dari TIS, atas kehendak ayahnya ia melanjutkan ke sekolah guru perempuan atau Meisjes Normaal School (MNS) yang mempunyai masa studi selama 4 tahun. Ia merasa cocok juga menjadi guru karena itu diturutilah kehendak ayahnya (Chudori, 1993:204). Lulus MNS dengan nilai memuaskan, S.K. Trimurti bisa langsung mengajar di Sekolah Latihan. Namun karena tidak betah dengan lingkungan di Sekolah Latihan ia memutuskan untuk keluar dan berpindah mengajar ke sekolah Ongko Loro di Alun-Alun Kidul kota Solo. Di sekolah ini pun S.K. Trimurti belum dapat menemukan ketenangan sehingga ia lagi-lagi berpindah ke Meisjesschool di Banyumas. Banyumas inilah yang menjadi pintu gerbang pertama bagi S.K. Trimurti mengenal dunia organisasi.

Pada saat itu seorang perempuan dianggap tabu jika mengikuti aktivitas politik maupun organisasi yang kebanyakan dilakukan oleh laki-laki. Setelah S.K.Trimurti dewasa, barulah ia menyadari bahwa ia tidak setuju dengan model aturan seperti itu dan ia menolak semua tata aturan dalam keluarganya. Baginya seorang perempuan mempunyai hak yang sama dengan laki-laki untuk memajukan diri baik dalam hal akademis maupun sosial. Karena itu sembari mengajar ia aktif menjadi anggota Rukun Wanita juga kerap mengikuti berbagai rapat-rapat yang diadakan oleh $\mathrm{BU}$ (Budi Utomo) cabang Banyumas (Chodori, 1993:205).

Agustus dan September 1932, Soekarno mengadakan perjalanan ke Jawa Tengah dan Jawa Timur guna membuka rapat-rapat umum Partindo. Salah satu kota di Jawa Tengah yang akan dikunjungi oleh Soekarno adalah Purwokerto. Sebagai perempuan muda yang haus akan nilai-nilai dan semangat perjuangan, ia ikuti rapat umum itu. Inilah untuk pertama kalinya S.K. Trimurti melihat dan mendengar secara langsung pidato Soekarno. Pesan utama pidato Soekarno yang ditangkapnya adalah bahwa bangsa Indonesia harus mulai bergegas untuk menerapkan anti imperialisme dan anti kolonialisme. Pidato Soekarno ini amat mempengaruhi jiwanya sampai akhirnya dengan tekad bulat dilepaskannya status sebagai guru negeri dan ia memilih bergabung dengan Partindo cabang Bandung. Keputusan besar yang sangat ditentang oleh keluarganya.

S.K. Trimurti memilih untuk bergabung dengan Partindo cabang Bandung karena ia ingin berguru langsung kepada Soekarno. "Saya sendiri masuk kepada partai politik itu pada tahun 1933. Waktu itu saya berada di Bandung. Saya berguru pada Bung Karno, belajar politik pada beliau." (Trimurti, 1986:116). Partindo cenderung lebih berani dan terbuka dalam menerima anggota baru serta mengadakan rapat-rapat umum. Selain itu juga non kooperatif. Inilah yang mempengaruhi model perjuangan S.K. Trimurti yang cenderung terbuka, berani mengambil resiko dan menolak kerjasama dengan Belanda.

Di Bandung ia tinggal bersama dengan kader-kader Partindo perempuan lainnya seperti Suprapti, Sukaptinah, Aminah Amatanis dan Nyonya Maskun. Di Partindo inilah ia mulai merangkak belajar tentang politik dan perjuangan. Sambil berpolitik S.K. Trimurti juga bekerja sebagai guru untuk menyambung hidup yaitu di sekolah swasta pimpinan Sanusi Pane bernama Perguruan Rakyat. Bersamaan dengan itu keluar peraturan mengenai vergader-verbod yang berisi larangan untuk mengadakan rapat-rapat. Larangan ini tidak dihiraukannya, ia tetap menjadi pembicara di suatu rapat umum yang diadakan oleh wanita. Pidato yang disampaikan oleh S.K. Trimurti cukup keras, bersemangat dan menyinggung pemerintah karena ia berbicara tentang anti penjajahan. S.K. Trimurti ditangkap kemudian diinterogasi walau tidak sampai di penjara. Setelah peristiwa itu nama S.K. Trimurti tercatat sebagai salah satu anggota partai yang mulai diincar keberadaannya oleh polisi Belanda.

Tanggal 1 Agustus 1933 Soekarno ditahan oleh pemerintah Belanda karena aktivitas politiknya. Soekarno dianggap menghasut rakyat untuk membenci pemerintah melalui 
rapat-rapat umum yang sering diadakan Partindo, juga tulisan-tulisannya di Fikiran Rakyat, dan pamflet-pamflet keluaran Partindo. Masuknya Soekarno ke penjara, sediki-sedikit mempengaruhi perjuangan Partindo. Ruh Partindo seperti hilang, semangat pun semakin lemah. Kondisi ini membuat S.K.Trimurti terpaksa kembali ke Klaten dimana orang tuanya saat itu berada.

Klaten yang senyap bukan kota yang tepat untuk S.K. Trimurti. Ia kemudian pergi ke Yogyakarta dan di kota inilah pada tahun 1935 ia mendirikan Pengurus Besar Persatuan Marhaeni Indonesia (PMI) bersama Sri Panggihan. Ketuanya adalah Sri Panggihan dan wakilnya adalah S.K. Trimurti. PMI beranggotakan banyak sekali mantan anggota organisasi Mardi Wanita - organisasi di bawah Partindo. Tujuan utama pendirian PMI selain memberikan pendidikan politik bagi para perempuan Indonesia juga untuk memperjuangkan kemerdekaan.

Keikutsertaan S.K.Trimuti di PMI dan keberaniannya untuk menyebarkan semangat perjuangan anti kolonialisme melalui pamfletpamflet gelap membuatnya harus rela dipenjara. Keluar dari penjara S.K. Trimurti tidak kapok dengan politik dan bergabung menjadi anggota Gerindo. Tokoh-tokoh Gerindo diantaranya Sartono, Amir Sjarifoeddin, Mohammad Yamin, dan A.K. Gani (Suhartono, 2001:91). Seringnya diskusi-diskusi politik mempertemukan S.K. Trimurti dengan lakilaki yang kemudian menjadi suaminya yaitu Mohammad Ibnu Sayuti atau kemudian biasa dipanggil Sayuti Melik. Walaupun berbeda partai politik -Sayuti Melik di Parindra- sama sekali tidak menghalangi keduanya untuk terus maju ke jenjang pernikahan.

Menjelang Jepang datang, S.K. Trimurti diciduk dan ditawan oleh Belanda karena dianggap sebagai pihak yang membela Jepang. Namun setelah Jepang benar-benar datang, ia justru ditangkap Jepang karena dituduh anti Jepang. Pada masa penjajahan Jepang semua organisasi dilarang, dengan terpaksa S.K. Trimurti atas permintaan Soekarno membantu pekerjaan di Putera dan kemudian Jawa Hoko- kai (Chodori, 1993: 223-224). Begitu memasuki persiapan kemerdekaan S.K. Trimurti adalah saksi diadakannya rapat-rapat BPUPKI, desakan kaum muda kepada Soekarno untuk segera memproklamasikan kemerdekaan, sampai hadir dalam upacara kemerdekaan 17 Agustus 1945.

Tak cukup sampai disitu karena S.K. Trimurti juga ikur serta menyebarkan berita kemerdekaan ke daerah-daerah. Ia juga menjadi anggota KNIP untuk membantu pekerjaan presiden sebelum dibentuknya DPR MPR. Suasana peralihan kekuasaan dari Jepang ke Indonesia tidak mulus, banyak mendapat tentangan dari prajurit Jepang. S.K. Trimurti mengalami sendiri bagaimana dahsyatnya pertempuran antara prajurit Jepang dan rakyat Indonesia di Semarang. Bahkan antar rakyat Indonesia sendiri pada peristiwa tiga daerah di Brebes, Tegal, dan Pemalang.

Pasca kemerdekaan, S.K. Trimurti memilih untuk menjadi anggota Partai Buruh Indonesia, bahkan kemudian menjadi ketuanya (Trimurti, 1986:119). Selain PBI, ia juga aktif di BBW (Barisan Buruh Wanita) sekaligus ia adalah ketuanya. BBW aktif memberikan kursus-kursus politik kepada kaum perempuan. Totalitasnya di bidang perburuhan membuatnya diangkat menjadi Menteri Perburuhan pada era kabinet Amir Sjarifoeddin.

Saat menjadi Menteri Perburuhan, S.K.Trimurti giat menjalankan tugasnya. Prestasi yang dicapai kemudian adalah lahirnya Undang-Undang Perburuhan yaitu UndangUndang Kecelakaan No. 33 tahun 1947. Selain itu Kementerian Perburuhan pimpinan S.K.Trimurti juga berhasil menyusun UndangUndang Kerja yang baru disahkan pada masa Kabinet Hatta tahun 1948. Perhatiannya terhadap pekerja perempuan sangat besar, sehingga Undang-Undang Perburuhan yang baru itu memuat beberapa pasal yang berkaitan dengan posisi perempuan. Diantaranya yang berkaitan dengan jam kerja perempuan. Perempuan dilarang dipekerjakan pada malam hari kecuali perawat dan bidan. Kebijakan tersebut berhubungan dengan kondisi pada waktu 
itu yang masih rawan. Bahkan ia juga mengeluarkan hak cuti haid bagi buruh perempuan (Chudori, 1993:229).

Pada perjalanannya, PBI bergabung dengan FDR (Front Demokrasi Rakyat) sebagai front yang menolak kebijakan pemerintahan masa Kabinet Hatta bersama partai-partai lain seperti Partai Sosialis, Partai Komunis Indonesia, dan Pemuda Sosialis Indonesia. Namun saat FDR hendak dilebur menjadi PKI atas inisiatif Muso, ia menolak. Inilah yang membuatnya lepas dari buruan tentara seperti teman-temannya lain yang menjadi anggota FDR/PKI, walaupun S.K. Trimurti juga sempat ditangkap dan secara maraton diinterogasi.

Lepas dari jabatan menteri, S.K. Trimurti menjadi anggota Dewan Nasional kemudian juga menjadi Dewan Perancang Nasional (Depernas) yang diketuai oleh Mohammad Yamin. Tahun 1959 presiden membentuk MPRS, SK.Trimurti ikut terpilih sebagai anggota di MPRS.

Memasuki masa Orde Baru tidak lantas membuat S.K. Trimurti pensiun dari dunia perpolitikan. Ia menjadi salah satu penandatangan naskah Petisi 50 atau biasa disebut juga "Pernyataan keprihatinan". Petisi 50 berisi tentang kritikan terhadap pidato Presiden Soeharto pada tanggal 27 Maret 1980 di depan rapat pimpinan ABRI yang diadakan di Pekan Baru. Selain itu Petisi 50 juga mengkritik pidato Presiden Soeharto pada HUT Kopassandhaa di Cijantung pada 6 April 1980. Pidato tersebut dinilai dapat menyebabkan pertentangan di antara masyarakat karena adanya sinyal mengganti makna Pancasila yang sesungguhnya. Disebut Petisi 50 karena ditanda-tangani oleh 50 orang tokoh masyarakat, mantan pejabat, dan mantan petinggi militer.

Keikutsertaan S.K. Trimurti menandatangani Petisi 50 bukan tanpa masalah karena pemerintah Orde Baru kemudian memberikan hukuman berupa pembatasan hak-hak sipil, isolasi, sampai pencekalan keluar negeri. S.K. Trimurti merasakan sendiri bagaimana ia dicekal ketika hendak mengunjungi anaknya yang saat itu sedang menempuh studi di
Amerika Serikat. Karena cekal akhirnya ia gagal berangkat. Kondisi itu tidak membuatnya takut apalagi berkecil hati, sebagaimana saat ia berjuang di masa penjajahan Belanda dan Jepang, dihukum adalah bagian dari resiko perjuangannya.

\section{BERJUANG DENGAN TULISAN}

Guru utama S.K. Trimurti dalam dunia tulis-menulis tak lain tak bukan adalah Soekarno. Soekarno adalah sosok yang pertama kali meminta S.K. Trimurti untuk menuangkan tulisannya di Fikiran Rakyat -majalah Partindo. Awalnya SK. Trimurti menolak karena ia merasa tidak cukup percaya diri dengan hasil tulisannya karena yang biasanya menulis di Fikiran Rakyat adalah tokoh-tokoh besar Partindo. Namun Soekarno adalah seorang guru yang baik sehingga selalu meyakinkan pada S.K. Trimurti bahwa ia pasti bisa. Akhirnya S.K. Trimurti memaksakan dirinya untuk menulis dan dimuatlah tulisannya yang pertama kali di media massa yaitu di Fikiran Rakyat.

Saat di Klaten untuk mengisi waktu dan agar semangat juangnya tidak padam, S.K.Trimurti menulis untuk surat kabar Berdjoeang pimpinan Doel Arnowo. Pada tahun 1935 ia dan teman-temannya di Solo mendirikan majalah Bedug yang bertujuan untuk komunikasi mengenai perjuangan rakyat dan untuk menggugah hati rakyat supaya sadar dengan nasibnya sebagai bangsa terjajah. Bedug menggunakan bahasa Jawa dengan harapan agar banyak dibaca oleh kalangan rakyat banyak. Namun majalah ini hanya bertahan satu kali penerbitan, kemudian berganti nama menjadi Terompet. Majalah Terompet menggunakan bahasa Indonesia, namun juga tidak bertahan lama.

Dunia menulis S.K. Trimurti dilanjutkan saat ia mendapat tugas untuk mengelola majalah Suara Marhaeni milik PMI. Setelah keluar dari penjara bulu semarang, S.K.Trimurti juga membantu mengisi tulisan di majalah Suluh Kita dan kadang-kadang membantu menyumbang tulisan di Sinar Selatan. Setelah 
menikah dengan Sayuti Melik, S.K. Trimurti bahkan mendirikan majalah sendiri yang bernama Pesat. Sayangnya majalah ini terpaksa ditutup ketika Jepang datang karena Jepang melarang semua surat kabar kecuali yang dikelola oleh Jepang sendiri.

Setelah merdeka, S.K. Trimurti tak meninggalkan dunia tulis-menulis. Melalui Api Kartini dan Harian Rakyat S.K.Trimurti kerap memperjuangkan nasib perempuan agar sejajar dengan laki-laki. Ia juga kerap mengkritik kebiasaan di masyarakat yang menganggap perempuan sebagai pelengkap atau hanya embelembel laki-laki semata. Tahun 1975 S.K. Trimurti bersama dengan teman-temannya mendirikan majalah bertemakan filsafat dan mental spiritual bernama Mawas Diri.

Iklim yang berbeda membuat S.K.Trimurti banting stir mengenai tema penulisan di majalahnya. Ia tak melulu menulis masalah politik, namun juga menulis tentang sosial ekonomi, wanita, dan perburuhan di Kedaulatan Rakyat, Majalah Gema Angkatan 45, Majalah Suara Perwari, Majalah Pradjoerit, Harian Nasional, dan Majalah Revolusioner. Ia beranggapan bahwa majalah politik tak lagi sesuai karena keadaan negara tidak lagi dijajah walaupun negara demokratis seperti yang ia dan teman-teman seperjuangannya impikan belum sepenuhnya terwujud.

\section{ORGANISASI PEREMPUAN}

Rukun Wanita adalah organisasi perempuan pertama yang diikuti oleh S.K.Trimurti. Walaupun aktif di dunia politik, ia juga tak melewatkan aktif di organisasi wanita seperti KOWANI (Kongres Wanita Indonesia). Ia pernah menjadi ketua kelompok II dalam Badan Pemeriksa Penggantian Undang-Undang dan Undang-Undang Perkawinan yang ditetapkan oleh kongres KOWANI di Solo pada tanggal 26-28 Agustus 1948 (de Stuers, 2008:178). S.K.Trimurti bertugas untuk menangani masalah yang berkenaan dengan pekerja perempuan. Di dalam badan itu SK.Trimurti tidak sendiri karena Badan Pemeriksa Penggantian Undang-Undang dan Undang-Undang
Perkawinan terdiri atas tiga kelompok. Kelompok pertama dipimpin oleh Maria Ulfah yang mengurusi tentang masalah sosial. Kelompok kedua dipimpin S.K.Trimurti dengan tugas masalah perburuhan. Kelompok ketiga dipimpin J. Sulianti yang berurusan dengan penelitian tentang kesehatan masyarakat.

Saat masih menjabat Menteri Perburuhan, perhatiannya terhadap perempuan memang sangat besar. Pada peringatan hari ibu tahun 1947 di alon-alon Yogyakarta, bersama dengan Presiden Soekarno, ibu negara Fatmawati, tokoh pergerakan perempuan Sri Mangunsarkoro dan tokoh perempuan lainnya, S.K. Trimurti ambi bagian. Bagi S.K.Trimurti perempuan adalah bagian dari kemerdekaan bangsa Indonesia sehingga setiap perempuan wajib untuk mengisi kemerdekaan dan menggunakan kesempatan sebaik-baiknya (Kedaulatan Rakyat, 22 Desember 1947).

Puncak dari keikutsertaan S.K.Trimurti dalam organisasi perempuan adalah saat dirinya bersama dengan beberapa teman seperjuangan mendirikan organisasi wanita yang dinamakan Gerwis (Gerakan Wanita Indonesia Sedar) (Chudori, 1993:230). Gerwis merupakan fusi dari berbagai organisasi perempuan yaitu Gerakan Wanita Rakyat Indonesia Kediri, Persatuan Wanita Sedar Surabaya, Rukun Puteri Indonesia Semarang, Persatuan Wanita Sedar Bandung, Persatuan Wanita Murba Madura (Soebagijo, 1982:195).

Perjalanan Gerwis semakin mantap dengan pelaksanaan kongres pada tanggal 3-6 Juni 1950. Kongres berhasil memilih pengurus besar Gerwis dengan ketua terpilih yaitu Tris Metty dari Semarang, ketua II Umi Sarjono dari Surabaya, sementara SK.Trimurti sebagai wakil dari Yogyakarta menjabat sebagai ketua III. Perjalanan waktu kemudian ternyata membuat Tris Metty sebagai ketua I Gerwis digeser dan digantikan oleh SK.Trimurti. Oleh beberapa anggota Tris Metty dianggap terlalu avonturir bahkan ada yang menganggap digesernya Tris Metty karena dia adalah seorang lesbian dan ia sangat terus terang dengan lesbianisme dirinya (Wieringa, 2010:217-218). 
Saat nama organisasi masih Gerwis, mereka konsisten untuk tidak berpihak pada kepentingan salah satu agama, komunis, dan organisasi politik sehingga tidak memiliki kaitan dengan partai politik mana pun. Namun sejalan dengan perubahan nama Gerwis yang berubah menjadi Gerwani ternyata cenderung pada salah satu partai politik pada pemilu 1955 yaitu PKI.

Pada masa menjelang tahun 1965, suami S.K. Trimurti yaitu Sayuti Melik membuat heboh dengan tulisannya di sebuah serial bernama Suluh Indonesia. Tulisan Sayuti mengupas tentang Marhaenisme yang menitikberatkan pada paham Nasasos (Nasionalis, Agama, dan Sosialis). Sayuti beranggapan bahwa Marhaenisme yang dicetuskan oleh Soekarno tidak dipengaruhi oleh Marxisme maupun Leninisme. Artikel tersebut sangat mengena bagi para anggota PKI yang sebelumnya menyalahartikan ajaran Soekarno. Kontan tulisan Sayuti itu membuat geger dan bahkan melahirkan BPS (Badan Pendukung Sukarnoisme) yang diketuai oleh Adam Malik.

S.K.Trimurti sebagai istri dari Sayuti Melik sang penulis artikel yang membuat heboh itu, tentu saja juga terkena getahnya. Selain rumah mereka sering didatangi oleh orang-orang PKI yang kebetulan kantor pusatnya dekat rumah mereka, ia juga dipanggil oleh pengurus Gerwani untuk datang ke kantor pusat. Sebenarnya sebelum peristiwa ini terjadi S.K.Trimurti sudah tak begitu aktif di Gerwani. Sejak Gerwis berubah nama menjadi Gerwani dan terlalu dekat dengan PKI, S.K. Trimurti merasa sudah lagi tak sehaluan. Menurut S.K. Trimurti beberapa keputusan penting Gerwani seolah-olah dibawah pengaruh PKI. Bahkan saat pemilihan ketua Gerwani, PKI menghalangi kepemimpinan S.K.Trimurti (Weiringa, 2010:225). Menurut Umi Sarjono "Trimurti sangat kecewa dengan dominasi PKI. Tokoh wanita yang mereka kehendaki dikirim dari atas, mereka itu umumnya orang baru di organisasi" (Weiringa, 2010:224).

Di kantor pusat Gerwani S.K. Trimurti ditanya oleh teman-temannya tentang artikel yang ditulis suaminya dan tentang pendirian BPS. S.K.Trimurti diminta memilih akankah ia mengikuti langkah organisasi atau mengikuti langkah suami. Dapat dipahami bahwa Gerwani dekat dengan PKI sehingga tulisan Sayuti Melik bagi Gerwani juga tidak menyenangkan. Akhirnya S.K. Trimurti memilih untuk berada di pihak suaminya. "Saya tidak dapat berdiri di atas dua perahu. Dengan ini saya menyatakan bahwa saya berdiri di samping suami saya!" (Soebagijo, 1982:214).

Setelah peristiwa itu berlalu, tahun 1966 S.K.Trimurti didaulat menjadi Ketua $\mathrm{V}$ bidang Ekubang (Ekonomi, Keuangan, dan Pembangunan) di lembaga DHN (Dewan Harian Nasional) Angkatan 45 pada konggresnya di Surabaya. S.K.Trimurti aktif di lembaga ini sampai menjelang tahun 1980-an. Saat duduk di DHN Angkatan 45 ia juga duduk di Lembaga Pembina Jiwa 45 -badan otonom di bawah DHN- yang diketuai oleh Mohammad Hatta. Badan ini bertugas untuk menjaga jiwa dan semangat perjuangan 1945.

Pada masa pembersihan MPR dari unsur-unsur PKI, dibentuklah MPRS yang berlaku sampai pemilu diadakan. S.K.Trimurti dipercaya untuk duduk di MPRS, hal itu seperti yang terjadi ketika masa pemerintahan Soekarno saat dirinya juga diminta duduk di MPRS setelah Soekarno mengeluarkan dekrit presiden 1959. Setelah itu S.K.Trimurti banyak menyibukkan diri pada YTKI (Yayasan Tenaga Kerja Indonesia) sebagai Dewan Pimpinan. Kegiatan YTKI lebih banyak pada kursus, pendidikan, lokakarya dan seminar tentang tenaga kerja Indonesia.

Perjuangan S.K.Trimurti untuk Indonesia merdeka mengilhami AJI (Aliansi Jurnalis Independen) mengabadikan nama SK. Trimurti sebagai anugerah atau penghargaan dengan nama S.K. Trimurti Award. Anugerah ini bertujuan untuk melestarikan semangat dan prinsip perjuangan S.K. Trimurti baik kepada aktivis perempuan atau jurnalis perempuan. Nama S.K. Trimurti dipilih sebagai ikon karena kesamaan gagasan dan semangatnya dengan visi AJI. S.K.Trimurti adalah salah satu tokoh kemerdekaan yang dipandang gigih 
memperjuangkan kebebasan pers, kebebasan berekspresi dan hak kaum tertindas terutama perempuan. Baik melalui karya-karya jurnalistik maupun lewat pengabdian sebagai aktivis perempuan dan politik.

Akhirnya, S.K.Trimurti sang wartawati yang begitu dekat dengan penjara baik sejak masa pemerintahan Belanda sampai pemerintahan Jepang, menyudahi goresan penanya di dunia pada 20 Mei 2008. Perempuan pejuang dari Sawahan ini meninggal dunia pada pukul 18.30 WIB di Rumah Sakit Pusat Angkatan Darat (RSPAD) Gatot Subroto, Jakarta Pusat (Kedaulatan Rakyat, 21 Mei 2008). Surastri Karma Trimurti meninggalkan bangsa yang telah diperjuangkannya pada usia 96 tahun. Tepat saat bangsa Indonesia merayakan 100 tahun hari kebangkitan nasional. Meninggalnya S.K.Trimurti bersamaan dengan meninggalnya Ali Sadikin yang meninggal di Singapura sekitar pukul 17.30 WIB pada usia 82 tahun (Kedaulatan Rakyat, 21 Mei 2008).

Sebelum meninggal SK.Trimurti menerima beberapa penghargaan dari pemerintah Indonesia yaitu Satya Lencana Peringatan Perjuangan Kemerdekaan (1961), Bintang Mahaputra Tingkat V (1961), Satya Lencana Perintis Pergerakan Kemerdekaan (1965), Anugrah Adam Malik Bidang Sastra (1989) dan Tetua Wartawan dari PWI Pusat dalam rangka hari pers nasional (1999).

\section{KESIMPULAN}

Melihat perjalanan hidup S.K. Trimurti sampai meninggalnya dapat disimpulkan bahwa pembentuk karakter S.K. Trimurti adalah lingkungan di sekitarnya yang menurutnya sangat tidak adil. Selain itu juga karena pergaulannya di dunia organisasi. Soekarno adalah salah satu tokoh yang berpengaruh dalam hidup S.K. Trimurti untuk membentuk jiwa kepribadiannya yang kuat dan anti penjajah. S.K. Trimurti terjun ke dunia pers juga karena permintaan Soekarno di majalah Fikiran Rakyat yang saat itu menjadi corong bagi Partindo.
S.K. Trimurti adalah saksi hidup perjuangan bangsa Indonesia saat dijajah Belanda dan Jepang. Merasakan sendiri bagaimana khidmatnya upacara proklamasi kemerdekaan Indonesia 17 Agustus 1945 dan ikut serta menyebarkan berita kemerdekaan sampai ke pelosok negeri Indonesia. S.K. Trimurti juga larut dalam suasana langsung peristiwa pertempuran di Semarang, heroiknya peristiwa tiga daerah di Karesidenan Pekalongan, dan dahsyatnya Peristiwa Madiun 1948.

Akhirnya kita bisa melihat bahwa sejarah tak lagi melulu milik laki-laki. Ada keseimbangan antara laki-laki dan perempuan dalam perjalanan sejarah, bahwa laki-laki dan perempuan secara bersamaan hadir dalam setiap lini sejarah di Indonesia.

\section{DAFTAR PUSTAKA}

De Stuers, Cora Vreede. 2008. Sejarah Perempuan Indonesia: Gerakan dan Pencapaian. Jakarta: Komunitas Bambu.

Ratih, I G.A.A. 2009. Jejak-Jejak Perbincangan Perempuan dalam Sejarah dalam Jurnal Perempuan 63

Kuntowijoyo. 2003. Metodologi Sejarah. Yogyakarta: Tiara Wacana.

Chudori, L.S.. 1993. SK. Trimurti dari Politik ke Kebatinan dalam Memoir Senarai Kiprah Sejarah, Diangkat dari Majalah Tempo. Jakarta: Pustaka Utama Grafiti.

Trimurti, S.K. Sukarno Si Pria dalam Wild, Colin dan Carey, Peter (penyunting). 1986. Gelora Api Revolusi: Sebuah Antologi Sejarah. Jakarta: Gramedia.

Soebagijo I.N. 1982. SK. Trimurti Wanita Pengabdi Bangsa. Jakarta: Gunung Agung.

Suhartono. 2001. Sejarah Pergerakan Nasional: dari Budi Utomo sampai Proklamasi 1908-1945. Yogyakarta: Pustaka Pelajar. 
Wieringa, S.E. 2010. Penghancuran Gerakan Perempuan: Politik Seksual di ndonesia Pasca Kejatuhan PKI. Yogyakarta: Galang Press.

"Wanita Pendorong Masyarakat", Kedaulatan Rakyat, 22 Desember 1947

"Duka Seabad Kebangkitan Nasional: Ali Sadikin dan SK.Trimurti Wafat", Kedaulatan Rakyat 21 Mei 2008 